\title{
Teaching Macro Excel on Pre-service Mathematics Teachers: Analysis Error in Solving the Syntax Manually
}

\author{
Nourma Pramestie Wulandari'1, Faishal Wahiduddin 2*, Ulfa Lu'luilmaknun³, \\ Mohammad Archi Maulyda ${ }^{4}$, Ratih Ayu Apsari ${ }^{5}$ \\ 1,3,5 Department of Mathematics Education, Universitas Mataram, Indonesia \\ ${ }^{2}$ Department of Computer Science, University of Central Florida, United States \\ ${ }^{4}$ Department of Primary Teacher Education, Universitas Mataram, Indonesia \\ 1nourmapw@unram.ac.id, 2faishal@knights.ufc.edu, ${ }^{3}$ ulfa 1@unram.ac.id, \\ 4archimaulyda@unram.ac.id, 5ra.apsari@unram.ac.id
}

\begin{abstract}
\section{Article History:}

Received : 31-10-2020

Revised : 18-03-2021

Accepted : 20-03-2021

Online : 16-04-2021

Keyword:

Macro Excel;

Pre-service Teachers;

Analysis Error;

Syntax Manually.

The aim of this study is to describe errors output when pre-service mathematics teachers were writing output of the syntax that given in macro excel manually. This research is a qualitative descriptive research with 101 participants from $2^{\text {nd }}$ year pre-service mathematics teachers from one of state university at Nusa Tenggara Barat, Indonesia. Instrument used consists of one syntax that has 8 outputs when it is run and that will be analysed using Newman's procedures. The eight outputs come from 3 types of output, namely text, numbers, and count. The result showed that the average percentage of syntax output writing errors was $87.13 \%$. It also indicated to reading errors of $48.51 \%$, comprehension errors of $18.81 \%$, transformation errors of $83.17 \%$, process skill errors of $20.79 \%$, and encoding errors of $87.13 \%$. Based on the result, errors occur when participants incorrectly write output and wrong in writing the result of the count. In addition, factors that caused these errors are 1) participants were not trained in providing information that was in the problem, 2) participants did not read the instructions in the problem correctly, and 3) participants did not pay attention to the suitability of syntax and output as was learned before. This research can be a reference for lecturers to develop learning about programming languages that can make students understand the use of syntax with the emphasis on manual syntax learning which will make their logic easier when applyng the syntax on a computer.
\end{abstract}

\section{A. INTRODUCTION}

Visual Basic of Applications (VBA) is a programming language included in Microsoft Excel, specifically in macro excel. VBA was first introduced in 1993, developed by Microsoft. VBA was added to Microsoft Office to enhance the development function in the future (Yan \& Hongliang, 2012). VBA is a programming language that is implemented in Microsoft Office ecosystem that was designed to help creating simple app, such as desktop app or to create a function determined by the user or to create a simple macro (Dydowicz, 2015). VBA has been available since Excel 5.0 and is a part of Visual Basic (VB) (Ribando, 2018). VBA has a more complete feature compared to VB. For example, upon creating tube illustration, VBA can move 
the hidden part of the tube and the user can easily manipulate the shape of the tube (Ribando, 2018). The VBA function is to automize the programs that are often used (Xi-xia et al., 2003)(Benefit of learning VBA in microsoft excel macro, 2020). VBA is more effective compared to spreadsheet MS Excel's processor when it comes to processing massive data, especially on creating matrix function that simulates database function (Dydowicz, 2015)(Benefit of learning VBA in microsoft excel macro, 2020), and is able to protect workbooks and hide worksheets (Benefit of learning VBA in microsoft excel macro, 2020).

VBA is taught to math education student on basic computer programming subject ats the university where this research was conducted. The teaching proses is conducted by giving the information about various VBA syntax that are used in macro excel along with the function and the instructions on how to use the syntax in macro excel. Beside learning to become good at using syntax, students are also required to understand the meaning of the syntax. So, in order to analyze the understanding, a test must be conducted. One of form of the tests is to write manual output of a syntax. Generally, the main purpose of teaching basic programming is to support students on learning programming concept and to achieve a beneficial skills that can be implemented when they become teachers (Xia, 2017). Students that have learned programming language found that VBA is an exciting and fun programming language for their skills (Ribando, 2018). VBA is one of the programming languages that are easy to learn where the visual programming technique enables the user to be better on creating application program (Hasana \& Alifiani, 2019).

Sometimes problem solving gives an inaccurate result. Error constitutes deviation from the right thing (Hadiyanto \& Wulandari, 2019). The mistake can be happen either because of not getting the complete information, not understanding the question, calculation errors, or because the weak knowledge about the material concept that has been learned before (Rohmah \& Sutiarso, 2018). According to Newman (Newman, 1977) there are 5 mistake types that can be happened when solving a problem in a question, they are reading error, comprehension error, transformation error, process skills error, and encoding error. Newman assumed that word problem is a series of hindrance whose solution needs to be found and failure on one of the hindrance prevents someone to move to the next hindrance to get the right solution ((Ken) Clements, 1980).

The previous researches regarding programming discuss about empirical study, program analysis, controlled experiment, survey, and interviews with learning model or programming product developer (Pang et al., 2018). Some of the researches are programming learning interaction using practice and theory on doing assignment in computer lab and also designing learning model or application to support programming language learning. (Shehane \& Sherman, 2014; Sophan \& Kurniawan, 2018; Thuné \& Eckerdal, 2019). Besides, there are other researches regarding Visual Basic Applications (VBA) such as analyzing excel suitability with VBA programming as a Monte Carlo simulation tool, developing mathematics understanding and students confidence by using VBA, developing a system that can support teachers to analyze program creating errors on novice programmer, including research on the effect of VBA based learning media towards student motivation (Bernard \& Senjayawati, 2019; Bhawkar et al., 2013; Botchkarev, 2015; Novianti et al., 2019). Based on the mentioned researches, it shows that there are still a few researches that discuss errors on creating output 
of a program manually. Therefore, the aim of this research is to describe the errors conducted by pre-service mathematics teacher along with the factors that affect errors conducted when writing out the output of VBA syntax in macro excel manually.

\section{B. METHODS}

This research is a descriptive-qualitative research with 101 sophomore students in mathematics study department from one of state university at Nusa Tenggara Barat, Indonesia as participants. Participants are selected using cluster sampling technique. The instrument used is one of the VBA syntax in macro excel that if it is run, it will show 8 outputs such as text, numbers and calculation results. All participants are given one VBA syntax in the same macro excel to be finished manually within 15 minutes. The answer of all participants were identified where the errors were made based on Newman's Procedure and continued by making a description of the type of errors. The answers will be later confirmed through interviews participants who make mistakes in solving problem to collect more accurate information. The result will be analysed using modification of Newman analysis as shown in Table 1.

Table 1. Newman's Error Indicators

\begin{tabular}{|c|c|c|}
\hline No. & Type of Error & Indicators \\
\hline 1. & Reading error & $\begin{array}{l}\text { a. Student is mistaken on reading terms, symbols, words or } \\
\text { important information of the question }\end{array}$ \\
\hline 2. & $\begin{array}{l}\text { Comprehension } \\
\text { error }\end{array}$ & $\begin{array}{l}\text { a. Student doesn't understand what is actually questioned } \\
\text { b. Error on catching the information in the question so student is } \\
\text { unbale to finish and step up to the next process }\end{array}$ \\
\hline 3. & $\begin{array}{l}\text { Transformation } \\
\text { error }\end{array}$ & $\begin{array}{l}\text { a. Student fails to convert the given syntax to become output } \\
\text { manually } \\
\text { b. Student is mistaken on writing types of output that is in form of } \\
\text { text, numbers and calculation result } \\
\text { c. Student is mistaken on placing the output }\end{array}$ \\
\hline 4. & Process skill error & $\begin{array}{l}\text { a. Student is mistaken on calculation or computation } \\
\text { b. Student doesn't continue solution procedure }\end{array}$ \\
\hline 5. & Encoding error & $\begin{array}{l}\text { a. Student doesn't write output manually according to the Microsoft } \\
\text { Excel display that pops up when the syntax is run correctly }\end{array}$ \\
\hline
\end{tabular}

\section{RESULT AND DISCUSSION}

Data analysis is conducted by identifying the percentage of the error type made by the participant on the syntax output written manually by referring to Newman's Procedure indicators. The given problem is "Pay attention to the macro excel syntax given in Figure 1. Create a visualization of the syntax when the program is run, under some conditions: 1) $a$ and $b$ values are the two last digit on the Students Identification Number (NIM), for example E1Rxxxxab; 2) the written output is submitted along with the row and column view in Microsoft Excel (at least displayed until the $16^{\text {th }}$ row and column C". Figure 1 is the given syntax.

The analysis result shows that only 13 participants $(12.87 \%)$ that can answer the question correctly. In the other words, there are 88 participants $(87.13 \%)$ that conducted errors on 
writing macro excel syntax output manually. The following Table 2 shows the percentage of the error type conducted by the participants based on Newman's Procedure.

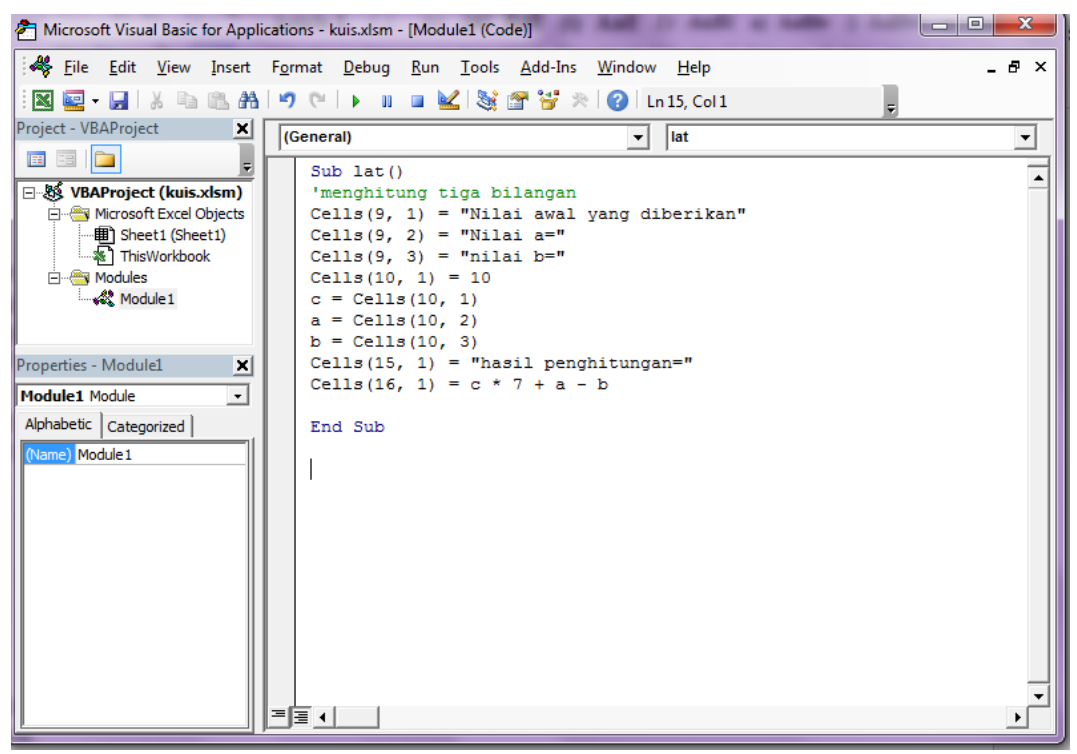

Figure 1. Syntax in macro excel

Table 2. Error type percentage based on Newman's Procedure

\begin{tabular}{lcc}
\hline Error Type & Frequency & Percentage (\%) \\
\hline Reading error & 49 & 48.51 \\
\hline Comprehension error & 19 & 18.81 \\
\hline Transformation error & 84 & 83.17 \\
\hline Process skill error & 21 & 20.79 \\
\hline Encoding error & 88 & 87.13 \\
\hline Total & \multicolumn{2}{c}{261} \\
\hline Mean percentage & \multicolumn{3}{c}{52.20} \\
\hline
\end{tabular}

\section{Reading Error}

Reading error happened because of the participant doesn't read information, terms, words or symbols in the question correctly. That, of course, will affect the whole solution process that will be done. In the other words, someone's ability to read information given in the question will affect the problem solving method (Oktaviana et al., 2017). Figure 2 shows an example of reading error conducted by the participant.

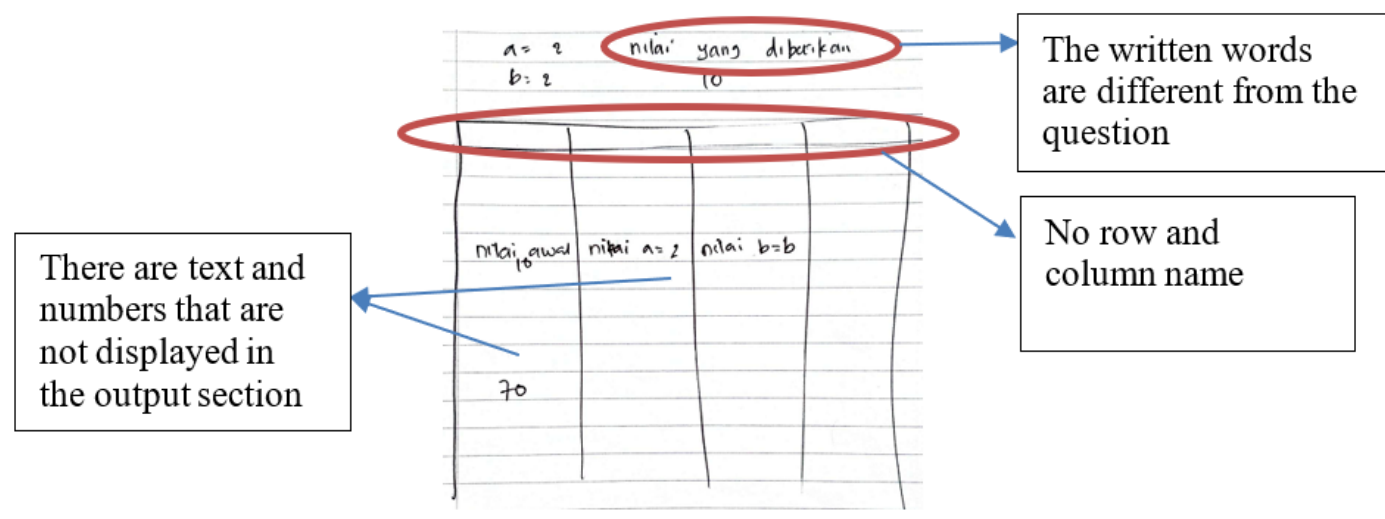

Figure 2. Reading Error Example 
Based on Figure 2, it can be seen that participant doesn't read the information in the question correctly. The provided answer doesn't have Microsoft Excel column and row when the program is run. Participant only write some of the syntax output without paying attention to the entire syntax so that the given visualization is not exactly same as it should be. Besides, there are some "calculation result" texts that are not written and there are value a and b writing that is not located at the designated spot. This finding corresponds with the previous research result that shows that in this type of error, someone can only plan the problem solving but are less able to execute the plan (Muttaqi et al., 2021). Besides, the interview result also states that participants don't know that the entire text must be written completely. Participants thought that only the numbers on the input section and the calculation result that needs to be written to be analysed by the lecturer. Besides, participants don't pay attention that the mentioned Microsoft Excel visualization supposed to include row and column name.

\section{Comprehension Error}

This type of error happened especially when someone doesn't understand what the question means. As a result, the given question can't be solved. Someone needs to understand what is being asked or ordered in order to pick an appropriate solution strategy. Someone can be classified as understanding the problem if the person can explain what is being asked in the question (Pratiwi, 2015). The following Figure 3 is an example of comprehension error conducted by the participant.

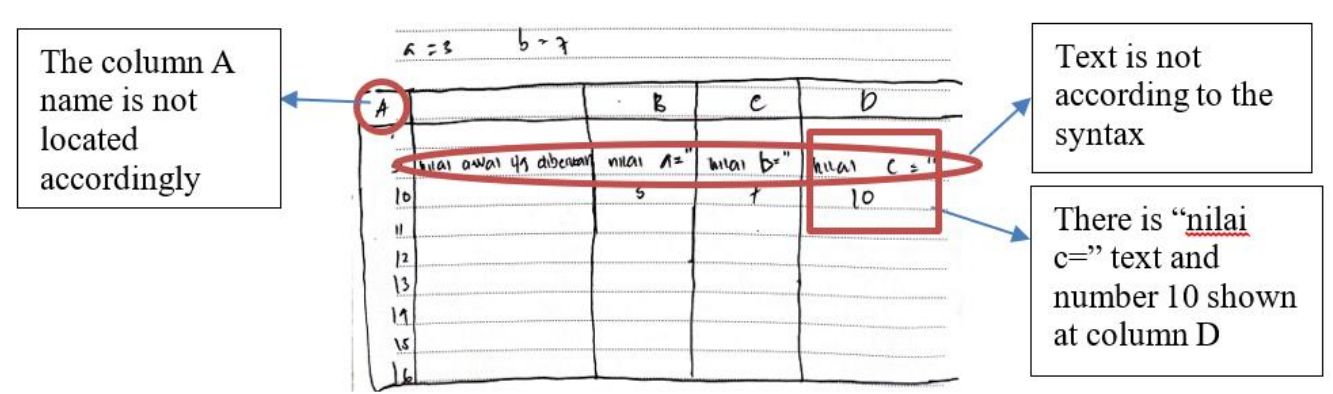

Figure 3. Example of Comprehension Error

Based on Figure 3, participant doesn't understand what is being asked in the question and therefore mistaken on understanding the information given in the question so that the participant can't proceed on solving the question. Further, Figure 3 also shows that the participant misplaced the c value that is supposed to be located in row 10 and column A. On the given syntax, there isn't any order to put c value in row 10 and column D so that the final two rows on the syntax is are not done and are not displayed in the output section. Because of this inaccurate information, the solution process is stopped and is not continued by writing the calculation result output that is supposed to be displayed in row 15 and column A. This finding is similar with the one from the previous research that shows when someone fails to understand the question requirement, then the person can't find an idea to finish the given mathematics problem, even when the person already converts the question into mathematical symbols or numbers (Alhassora et al., 2017). Another research also shows that students conducted some errors because of the failure to understand the whole question information and can't interpret what is required to solve the question (Rohmah \& Sutiarso, 2018). 
The output writing on Figure 3 shows that the text that will be displayed when syntax is run is also incorrect and even the column A name writing is misplaced. The column A location on the answer is located on the dedicated column to show rows on Microsoft Excel. As an addition, the output result of a syntax should be written accordingly to the written order or question. For example, a programmer writes "numbers" on the syntax, it is impossible that when the program runs the displayed result will be "numbers" or even other no similar texts. This is supported by the interview result that shows that the participant doesn't understand what are needed to be written on the answer sheet. Participant doesn't understand that the output display should be according to the given syntax. Besides, participant states that he is confused when it comes to calculation process, which number that should be involved in the process and where to write the result.

\section{Transformation Error}

Transformation error happens because participant can't write the syntax output manually exactly the same with the one if it's run in a program. In other words, participant fails to convert syntax into the corresponding output. This can be happened because of the inaccuracy on deciding the solution strategy (Sumule et al., 2018). This fact is supported by Figure 4 that shows that the participant did a mistake on writing the output type that is supposed to be numbers which is the initial number, 10, in row 10 and column A. But it is seen that the participant writes $c=10$. The 10 -value giving process in variable $c$ is only happened in the program's memory and will not be displayed as an output. Besides, Figure 4 also shows that the participant did a mistake in the row 16 and column A that is supposed to shows only the calculation result. The fact is, the participant also writes the calculation process completely in the output section. This is caused by transformation error conducted when writing c value, so that it affects the solution process entirely. The previous research shows that transformation error can cause error to the whole solution process, especially in the calculation process (Yunus et al., 2019). As an addition, based on the interview result, it is known that the participant thinks that the solution process must be written as an answer. The participant doesn't know that the calculation process is not included in the resulting output. The solution result with transformation error is completely shown in the following Figure 4.

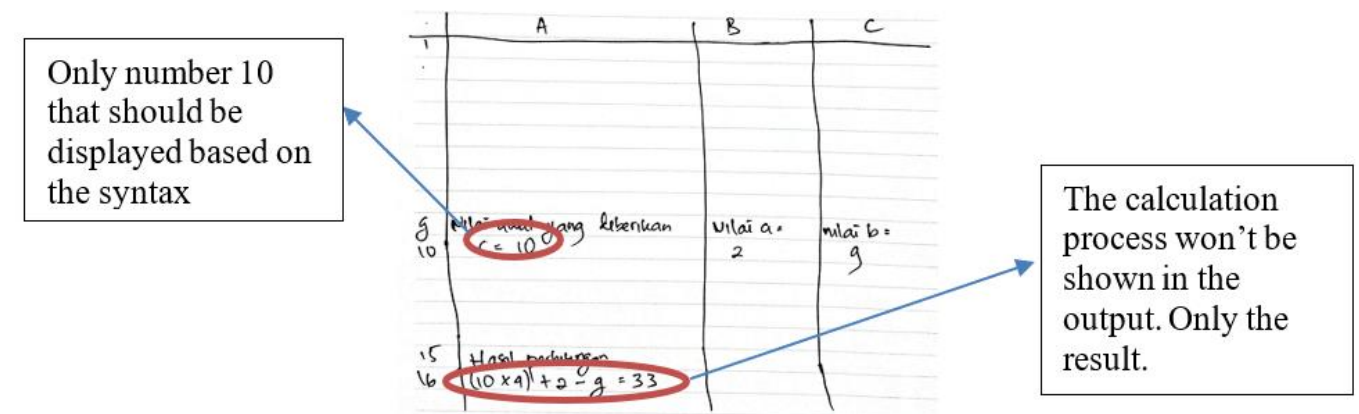

Figure 4. Example of Transformation Error

\section{Process Skill Error}

This error type is usually detected on the calculation phase that is conducted by the participant. Each value that is put on the corresponding row and column will be then processed on the calculation process that involves adding, subtracting, and multiplying 
calculation operation. Another mistake that participant did is the text writing and output row location that is not corresponding to the syntax. In Figure 5, output is located in row 4, row 5, row 8 and row 9. Nonetheless, it can be stated that participant understands what is required by the question by is not meticulous enough to calculate the given numbers in the program accurately. This is related to student's number sense ability, which is the ability to understand and implement numbers along with its operations to solve problems related to numbers flexibly and efficiently (Andrews \& Sayers, 2015; McIntosh et al., 1992). Figure 5 shows an example of process skill error conducted by the participant.

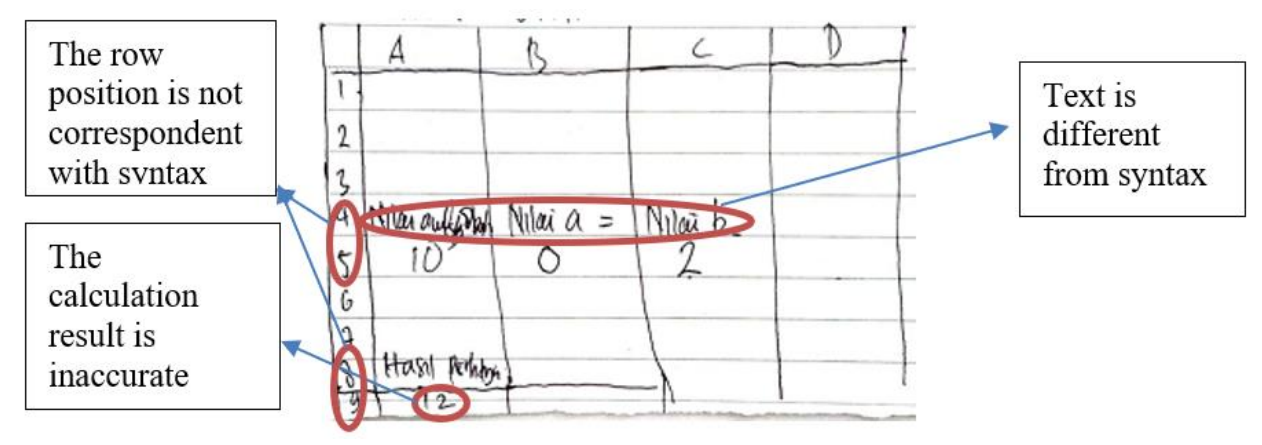

Figure 5. Example of Process Skill Error

Based on Figure 5, it can be seen that the calculation result written by the participant in the output is 12 . If we go through Figure 1, the result of the calculation is supposed to be 68 . This result comes from the given initial value (c-value), which is 10 and the last 2 digits of NIM that applies as a and $b$ value so that with the given syntax, the calculation should be $10 \times 7+$ $0-2=68$. At this phase, participant doesn't multiply c value with 7 in the first place. Participant only does the summary and subtraction of the whole value. That is why the written result is not accurate. Based on the interview, it is known that the participant admitted that he is not meticulous and hasty in calculating based on the formula that is located on the final row of the syntax and in writing the text corresponding to the syntax. Because of that, some calculation and visualization mistakes are happened. Participant realizes the mistakes that is conducted and written on the answer sheet when the interview is conducted.

\section{Encoding Error}

This type of error happens when someone doesn't write the whole output visualization of the syntax manually and not corresponding to the Microsoft Excel interface. In this type of error, participant can write the types of output such as text, numbers, or even the calculation result correctly. However, the drawn visualization of Microsoft Excel row is incomplete. Participant only writes row 1 to show the start of the row, and then jumped to row 9, row 10, row 15 and row 16 that is used to display the output whereas in Microsoft Excel, the row numbering will be given automatically in order. Therefore, the final result is still incorrect. Generally, this is in comparation with the process to create a final conclusion on answering given problems or questions. A rechecking phase is needed to make sure that all the answers are corresponding to the requirements and can answer the given question (Ayuningtyas et al., 2019). If the phase is not conducted, then there is a big chance for mistakes to happen from the problem-solving result (Puspa et al., 2019). This is supported by the interview result with 
the participant that states that he didn't recheck the solution result accurately. Participant assumes that the row numbering only involves the row that becomes the part of the answers. The following Figure 6 shows the encoding error.

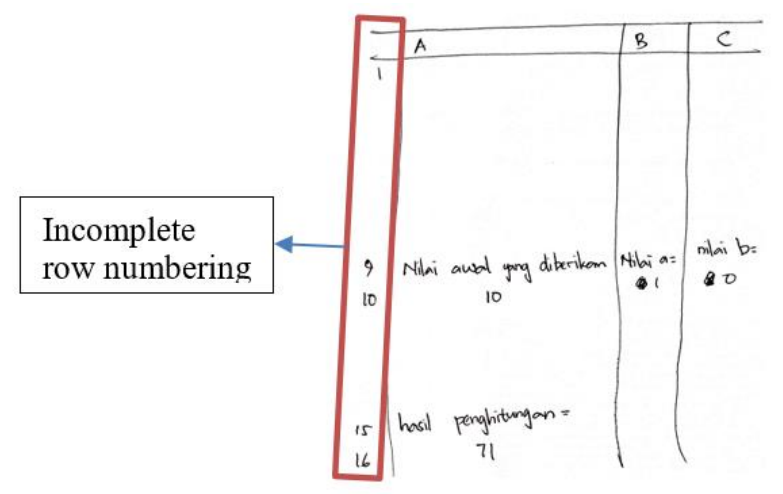

Figure 6. Example of Encoding Error

Generally, participant is not careful on looking at the given information in the question. The given syntax is only written by some means that according to the participant are the same. Participant doesn't realize that the output result difference on words abbreviation, incomplete sentences, and the capitalized letters will affect the grading to the solution. For example, in writing "the given initial value", there are some participants that only write it "initial value". Furthermore, almost all participants state that they don't pay attention if the text writing has to be exactly same with the syntax even though they have been taught before and practiced it in Basic Computer Programming class. Someone's inability to finish a question correctly can also be affected by the weak basic knowledge factor so that it causes someone to be unable to implement the knowledge to solve the problem (Alhassora et al., 2017; Rohmah \& Sutiarso, 2018).

\section{CONCLUSION AND SUGGESTIONS}

The result showed that the average percentage of syntax output writing errors was $87.13 \%$. The results also indicate to reading errors of $48.51 \%$, comprehension errors of $18.81 \%$, transformation errors of $83.17 \%$, process skill errors of $20.79 \%$, and encoding errors of $87.13 \%$. Based on the result, in generally, errors occur when participants incorrectly write the text and put the output's position, and wrong in writing the result of the count. In addition, factors that caused these errors are 1) participants were not trained in providing information that was in the problem, 2) participants did not read the instructions in the problem correctly, and 3) participants did not pay attention to the suitability of syntax and output as was learned before. To the next researcher can try to find analysis error in solving for other syntax.

\section{ACKNOWLEDGEMENT}

Thank to Department of Mathematics Education, Faculty of Education and Teacher Training, Universitas Mataram for giving the support in this study.

\section{REFERENCES}

Alhassora, N. S. A., Abu, M. S., \& Abdullah, A. H. (2017). Newman Error Analysis on Evaluating and Creating Thinking Skills. Man In India, 97(19), 413-427.

Andrews, P., \& Sayers, J. (2015). Identifying opportunities for grade one children to acquire 
foundational number sense: Developing a framework for cross cultural classroom analyses. Early Childhood Education Journal, 43(4), 257-267. https://doi.org/10.1007/s10643-014-0653-6

Ayuningtyas, W., Mardiyana, \& Pramudya, I. (2019). Analysis of student's geometry reasoning ability at senior high school. Journal of Physics: Conference Series, 1188, 1-8. https://doi.org/10.1088/1742-6596/1188/1/012016

Benefit of learning VBA in microsoft excel macro. (2020). TED Learning.

Bernard, M., \& Senjayawati, E. (2019). Developing the Students' Ability in Understanding Mathematics and Self-confidence with VBA for Excel. JRAMathEdu (Journal of Research and Advances in Mathematics Education), 1(1), 45-56. https://doi.org/10.23917/jramathedu.v1i1.6349

Bhawkar, A., Belsare, R., Gandhi, F., \& Somani, P. (2013). Analysis of errors - A support system for teachers to analyze the error occurring to a novice programmer. IJCSN International Journal of Computer Science and Network, 2(5), 2277-5420. www.ijcsn.org

Botchkarev, A. (2015). Assessing excel VBA suitability for monte carlo simulation. Spreadsheets in Education (EJSiE), 8(2), 1-30. http://arxiv.org/abs/1503.08376

Dydowicz, P. (2015). Creation and use of internal matrix database functions in VBA MS Excel environment for bulk data processing. Journal of Software and Systems Development, 2015(2015), 1-12. https://doi.org/10.5171/2016.675401

Hadiyanto, F. R., \& Wulandari, N. P. (2019). Identifikasi Kesalahan Siswa Kelas VII dalam Menyelesaikan Soal Cerita Geometri dengan Newman's Procedure. Mandalika Mathematics and Education Journal, 1(2), 1-7.

Hasana, S. N., \& Alifiani, A. (2019). Multimedia development using visual basic for application (VBA) to improve students' learning motivation in studying mathematics of economics. Indonesian Journal of Mathematics Education, 2(1), 34. https://doi.org/10.31002/ijome.v2i1.1230

McIntosh, A., Reys, B. J., \& Reys, R. E. (1992). A Proposed Framework for Examining Basic Number Sense. For the learning of mathematics. For the Learning of Mathematics, 12(3), 2-8. http://area.dgidc.min-edu.pt/materiais_NPMEB/008_Texto_sentido_numero_Mcintosh.pdf

Muttaqi, U. K., Kartono, K., \& Dwidayanti, N. K. (2021). Diagnostic analysis of Newman's types of students ' error in finishing questions of mathematical problem solving. Unnes Journal of Mathematics Education Research, 10(1), 32-40.

Newman, M. A. (1977). An analysis of sixfll-grade pupils' errors on written mathematical tasks. Research in Mathematics Education in Australia, 1, 239-258.

Novianti, V., Sa'adah, N., \& Chotimah, S. (2019). Pengaruh penggunaan media pembelajaran berbasis VBA for excel terhadap motivasi siswa SD pada materi bangun datar. Journal On Education, 02(01), 110-116.

Oktaviana, D., Newman, K. K., \& Diskrit, M. (2017). Analisis tipe kesalahan berdasarkan teori newman dalam menyelesaikan soal cerita pada mata kuliah matematika diskrit. EduSains: Jurnal Pendidikan Sains \& Matematika, 5(2), 22-32.

Pang, A., Anslow, C., \& Noble, J. (2018). What programming languages do developers use? A theory of static vs dynamic language choice. Proceedings of IEEE Symposium on Visual Languages and Human-Centric Computing, VL/HCC, 239-247. https://doi.org/10.1109/VLHCC.2018.8506534

Pratiwi, D. D. (2015). Analisis Kemampuan Komunikasi Matematis dalam Pemecahan Masalah Matematika Sesuai dengan Gaya Kognitif dan Gender. Al-Jabar: Jurnal Pendidikan Matematika, 6(2), 131-141. https://doi.org/https://doi.org/10.24042/ajpm.v6i2.28

Puspa, S., Riyadi, R., \& Subanti, S. (2019). Profile of mathematical communication skills junior high school students in problem solving. Journal of Physics: Conference Series, 1157. https://doi.org/10.1088/1742-6596/1157/3/032125

Ribando, R. (2018). An Excel/visual basic for applications ( VBA ) programming primer. RJ Ribando, 18, 1-19.

Rohmah, M., \& Sutiarso, S. (2018). Analysis problem solving in mathematical using theory Newman. EURASIA Journal of Mathematics, Science and Technology Education, 14(2), 671-681. https://doi.org/10.12973/ejmste/80630

Shehane, R., \& Sherman, S. (2014). Visual teaching model for introducing programming languages. Journal of Instructional Pedagogy, $14,1-8$. http://www.aabri.com/OC2014Manuscripts/OC14005.pdf 
Sophan, M. K., \& Kurniawan, A. (2018). Perancangan aplikasi learning by doing interaktif untuk mendukung pembelajaran bahasa pemrograman. Jurnal Teknologi Informasi Dan Ilmu Komputer (JTIIK), 5(4), 455-464. https://doi.org/10.25126/jtiik

Sumule, U., Amin, S. M., \& Fuad, Y. (2018). Error analysis of Indonesian junior high school student in solving space and shape content PISA problem using Newman procedure. Journal of Physics: Conference Series, 947, 1-6. https://doi.org/10.1088/1742-6596/947/1/012053

Thuné, M., \& Eckerdal, A. (2019). Analysis of Students' learning of computer programming in a computer laboratory context. European Journal of Engineering Education, 44(5), 769-786. https://doi.org/10.1080/03043797.2018.1544609

Xi-xia, M. A., Feng, W. A. N. G., \& Qiao-hua, M. A. (2003). Application of VBA in the Optimal Selection of Hydrologic Statistic Parameters. Journal of Zhengzhou University(Engineering Edition), 24(2), 6769.

Xia, B. S. (2017). An in-depth analysis of learning goals in higher education: Evidence from the programming education. Journal of Learning Design, 10(2), 25. https://doi.org/10.5204/jld.v10i2.287

Yan, W., \& Hongliang, H. (2012). Hydropower Computation Using Visual Basic for Application Programming. Physics Procedia, 24, 37-43. https://doi.org/10.1016/j.phpro.2012.02.007

Yunus, J., Zaura, B., \& Yuhasriati, Y. (2019). Analysis of Students Error According to Newman in Solving Mathematics Problems of Algebra in The Form of Story in Second Grade of SMPN 1 Banda Aceh. Jurnal Geuthèe: Penelitian Multidisiplin, 2(2), 308-313. 